\title{
SAVE AND LOAN CREDIT INFORMATION SYSTEM BASED ON WEB
}

\author{
Eddis Syahputra Pane \\ Information System Department, Faculty of Computer Science, \\ Universitas Lancang Kuning \\ jugulspane@gmail.com
}

Received : 24 October 2020, Revised: 10 November 2020, Accepted : 11 November 2020

\begin{abstract}
Pancuran Hidup Credit Union is a cooperative engaged in a savings and loan business that provides loans for its members. In its development often encountered an error due to lack of accuracy of employees in processing data processing transactions and savings and loans that still use the manual system that is using Microsoft Office. This manual system is less effective because the savings and loan transactions that occur are higher so that the calculation is even more numerous, and therefore requires an information system. The purpose of this research is to create a web-based savings and loan information system that helps make it easier for employees to manage member data and savings and loan transactions at the Pancuran Hidup Credit Union. In this study the authors used the Waterfall Model analysis method. The SDLC waterfall model is often also called the linear sequential model or classic life path. Based on the problems that have been discussed and resolved through this report, the conclusion can be drawn about the Savings and Loan Information System for the Union of Living Credit Pekanbaru based on Web, Information Systems can facilitate the cooperative in making reports more quickly and produce accurate data
\end{abstract}

Keywords : Information System, Savings and Loans, Web, Saving and Loan Cooperative Pancuran Hidup

\section{Introduction}

The development of information technology in various fields life is so fast, encouraging people to compete to use information technology according to their needs and goals. Utilization of information technology in a company or organization is of course in accordance with the nature and level of requirements of the system. The world of the internet is growing rapidly with the progress of the times(Dao, et.al., 2011).

Inevitably, in a relatively short period of time, Internet and web usage in Indonesia from year to year has increased significantly. Technological developments in Indonesian cooperatives can also be seen from the existence of information systems and technology to facilitate the process of disseminating information, managing data and saving and borrowing members. However, not all cooperatives in Indonesia have taken advantage of developments in information systems and technology, one of which is the Pancuran Hidup Credit Union cooperative.

Pancuran Hidup Credit Union is a cooperative engaged in a savings and loan business that provides loans to its members. The cooperative which was founded in 2003 is located on Jl.Dharma Bakti, Sigunggung-Pekanbaru and already had 10,045 members as of the end of 2019 (including inactive and inactive members amazing members). The scope of its membership includes cities Pekanbaru and its surroundings. In its development it is often encountered The existence of data input errors, loss of data, the occurrence of double data and the slow presentation of reports from the data processing were obstacles in the Pancuran Hidup Credit Union. This is due to the lack of accuracy of employees in the processing of data processing transactions and savings and loans which still use the manual system, namely by using the Microsoft office such as Microsoft word and Microsoft Excel. Moreover, the data that is processed quite a lot will affect the efficiency of time and energy. This manual system is less effective because the savings and loan transactions that occur are higher so that the calculation is even more numerous and requires great accuracy. With these problems, Credit Unions need a savings and loan information system that can assist in processing data and savings and loans faster, easier, producing more accurate, effective and efficient data. 


\section{Literature Review}

Information system is a goal to store, process and communicate information. Information systems are used by all users in the organization. The form of information needed for lower-level leaders is detailed, in the form of a combination of fifty percent of details and fifty percent of summaries, while for top-level leaders it is in the form of summaries(Taiwo, 2016). Cooperation, which means working together, so that every form of cooperation can be called a cooperative. In general, cooperatives are understood as associations of people who voluntarily unite themselves to fight for the improvement of their economic welfare through the formation of a business entity that is managed democratically(Majee \& Hoyt, 2011).

In the system development phase, the author uses the System Development Life Cycle (SDLC) Framework with the waterfall approach which consists of several stages of activity flow that run in one direction from the beginning to the end of the system development project(Stoica, et. al., 2013). The Waterfall Method, There are several stages - certain stages that must be reached in the same direction after another, in a particular order, such as a staircase or a multilevel waterfall. There are many different stages in this method, in general it is a feasibility study, requirements, architecture, design, development, testing, deployment and operation(Balaji, S., \& Murugaiyan, M. S., 2012).

SDLC (System Development Life Cycle) has several models in the application of the stages of the process. One of them is the SDLC waterfall model, which is often called a linear sequential model or classical life cycle. The waterfall model is the simplest SDLC model. This model is only suitable for software development with unchanging specifications. The waterfall model provides a sequential or sequential approach to the software life flow starting from the analysis, design, coding, testing, and support stages(Kannan, et.al., 2014).

Research conducted by Wati \&Siahaan (2017) with title "Analysis and Design of Cooperative Information System Save Web-Based Lending at MTs Negeri Talang Bakung Jambi City ".The research objectives are: to analyze and study the problems web-based savings and loan information system at MTs Negeri Talang Bakung, using the prototype method, the results of this study bring various conveniences, including the ease in processing the registration process for cooperative members, storage, borrowing, and returns, ease in making reports that are faster and more accurate, so that errors in saving and loan recording activities can be avoided. The difference in previous research is that previous research used the prototype method while the author used the waterfall method.

Research conducted by Rahmawati, et.al. (2016) with the title "Web-Based Cooperative Savings and Loan Information System". The research objectives are: accelerating employees in the processing of savings and loan data and making it easier for members to obtain transaction information in cooperatives. The method used is the waterfall method, the results of this study: 1. This web-based computerization can be an alternative solution to the problem of inputting data for members who continue to increase and processing data on savings and loan transactions as well as making it easier to produce reports every month at the Prosperous Cooperative PT. Induro International. 2. Speed up the data processing. 3. This website can be a means of online information that can be accessed by cooperative members anywhere and anytime. 4. Data storage using a computerized system rated safer. The difference in previous studies is previous research using ERD (Entity Relationship Diagram) while the authors designed using UML (Unified Modeling Language).

Research conducted by Aris, et.al., (2016) with the title "Applications Savings and Loans Information System On Koperasi Usaha Bersama Syari'ah At-Tahwil Kota Tangerang ”. Research objectives, namely: making applications that can help problems that are happening, using a visual paradigm program. Results of the research: To facilitate the At-Tahwil syariah cooperative in obtaining accurate information about the Savings and Loans Application system at the At-Tahwil Syariah Koperasi. This Savings and Loans information system application can make it easier for the Admin to be able to perform the data entry process and convey information quickly to members. The difference in the previous research is that the previous study used the visual paradigm program, while the writer used the Php programming language and the MySql database. 


\section{Research Methods}

This research methodology relates to the methods, techniques, patterns, and research designs used by the author in sorting the work to be carried out in the research, thus helping and making it easier for the writer to know the stages and also the research process. This research process the author aims to understand how to design a web application with the waterfall method in the Pancuran Hidup Credit Union Savings and Loans Cooperative. The steps taken in this research are:

\section{Problem Analysis}

This stage is carried out to understand the problems that have been determined limiting problem in this study. By analyzing the problem hopefully the problem can be understood well. As for the stages the analysis used is: identifying the problems that occur, by understanding more about the problem at hand collect the required data, look for system weaknesses and gather information about user needs.

\section{Data Collection}

At this stage the author is to get the data and information accurate which can support the research process.

\section{Application Implementation}

At this stage the authors designed a Web-based Savings and Loans Information System at the Pancuran Hidup Pekanbaru Credit Union.

\section{Testing}

System testing is carried out to ensure that the systems are made in accordance with the design and all functions can be used properly without errors according to user needs. Testing this system using the Blackbox Testing method. Testing is carried out thoroughly regardless of the internal structure or components being tested. Blackbox Testing focuses on the functional requirements of a system based on the specifications of the system requirements.

\section{Results and Discussions}

The system analysis stage aims as the basis for designing or repairing the old system. From the results of this analysis, it can be designed or improved into a system that is more effective and efficient. To increase the speed and accuracy of both data input, data processing, and output results, the research site requires a more efficient application given the increasingly rapid technological advances, it is necessary to have a website-based savings and loan information system at the Pancuran Hidup Credit Union Cooperative.

In designing this website-based information system media, it can be done by making a system design design according to the needs of the Pancuran Hidup Credit Union Cooperative. This application can later be used by the Admin and the Head of the Pancuran Hidup Credit Union Cooperative to be able to view information about member savings and loans. This application will display several system requirements:

1. Information from the Pancuran Hidup Credit Union Cooperative

2. Members' savings and loan data that can be managed by the admin The following below is the result of implementing the system : 


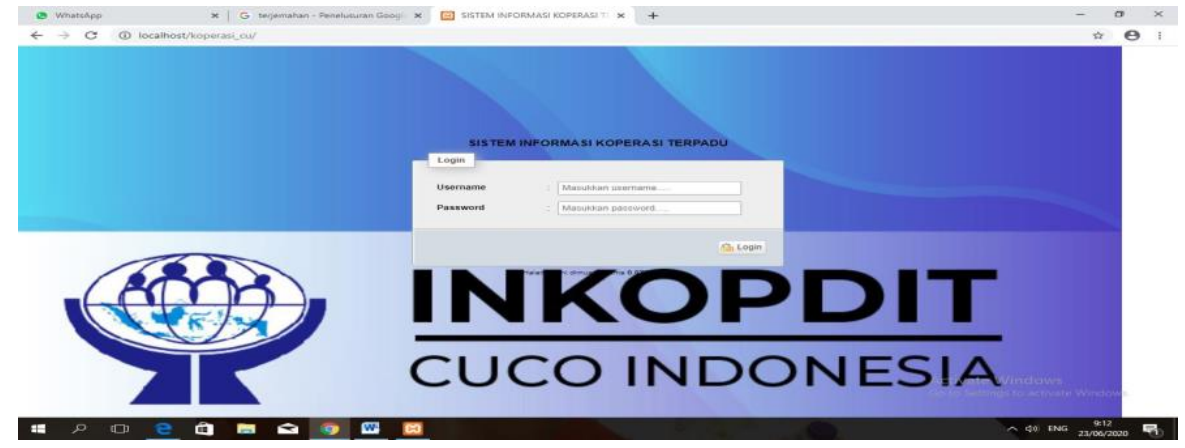

Fig. 1. Login Page

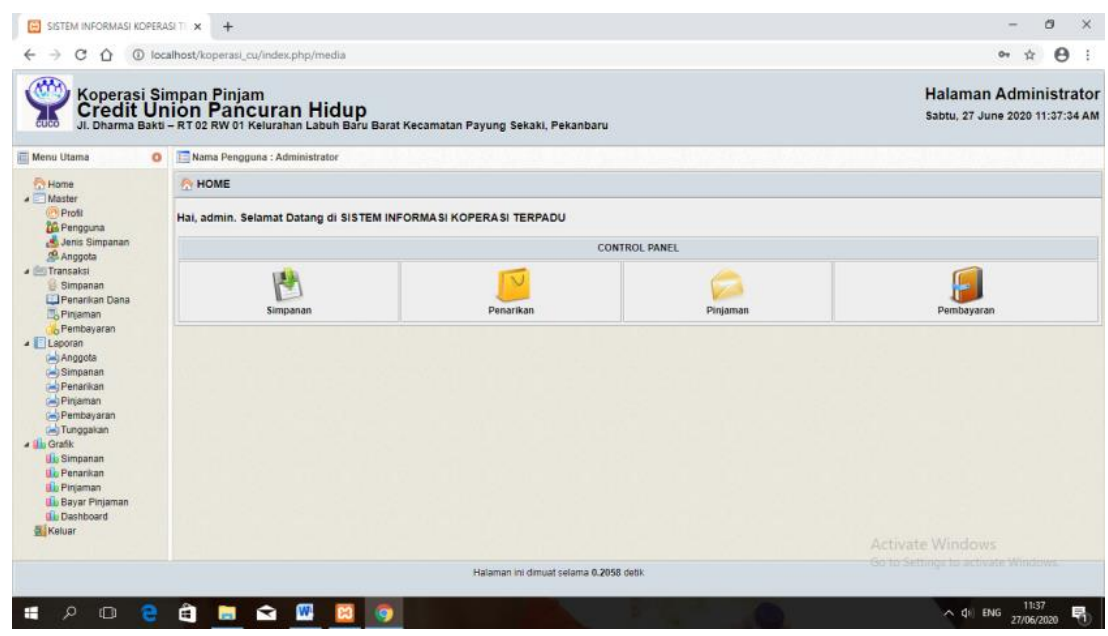

Fig. 2. Admin Main Page

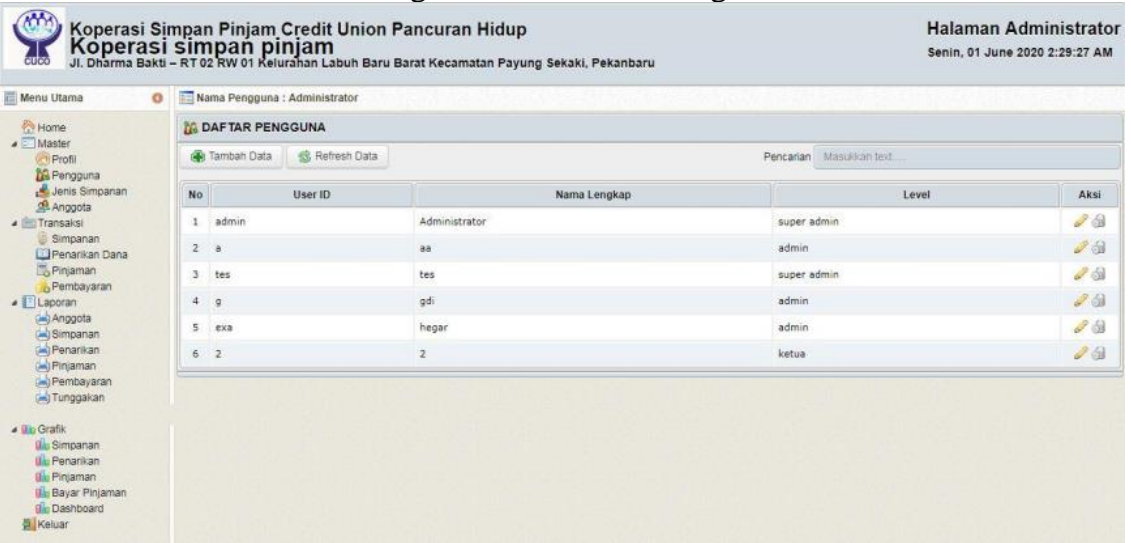

Fig. 3. User Main Page

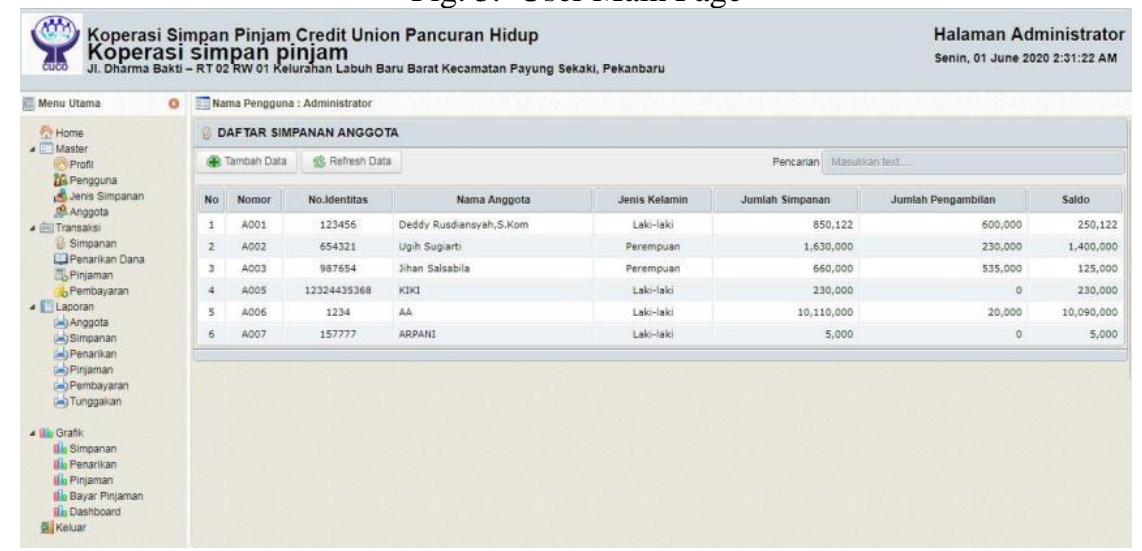

Fig. 4. Deposit Data Page 


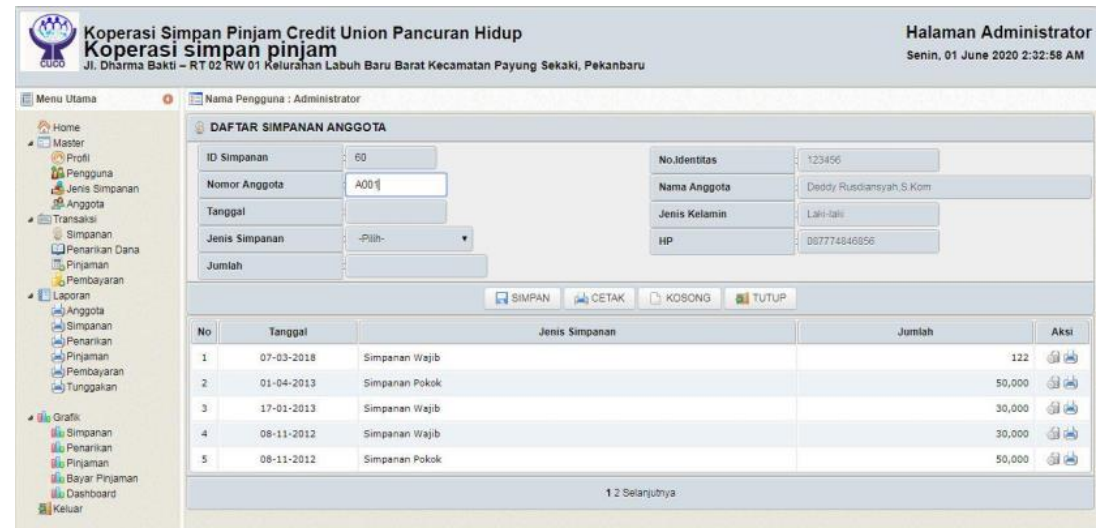

Fig. 5. Admin page Adds Member Deposit Data

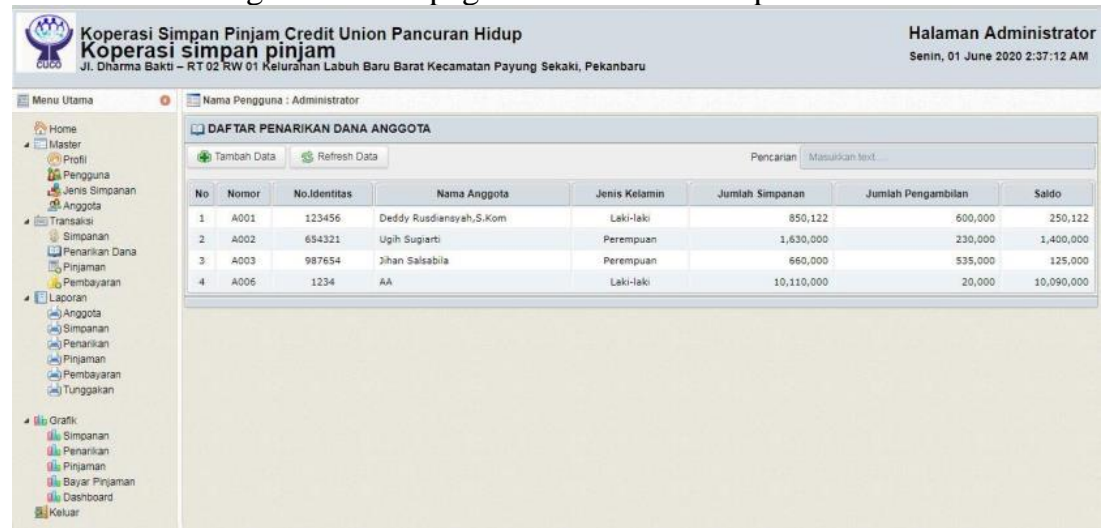

Fig. 6. Admin page of Member Fund Withdrawal Data

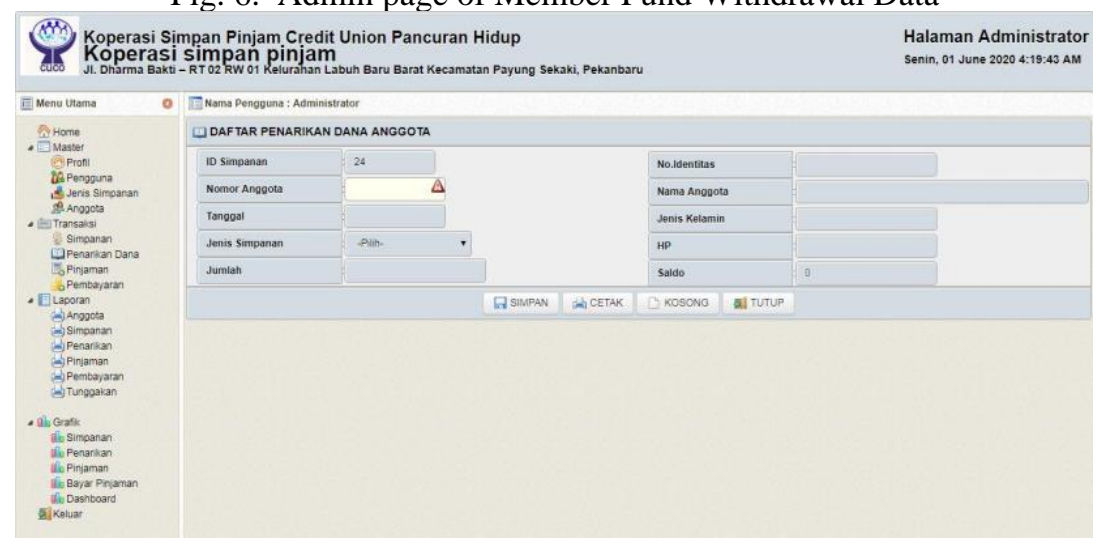

Fig. 7. Add Member's Fund Withdrawal Data page

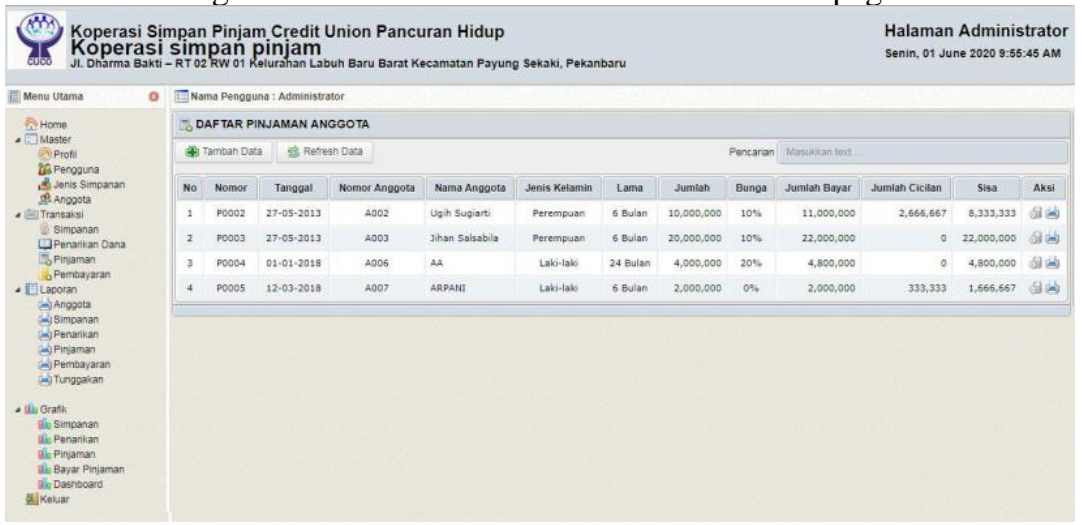

Fig. 8. Admin page Adds Member Loan Data 


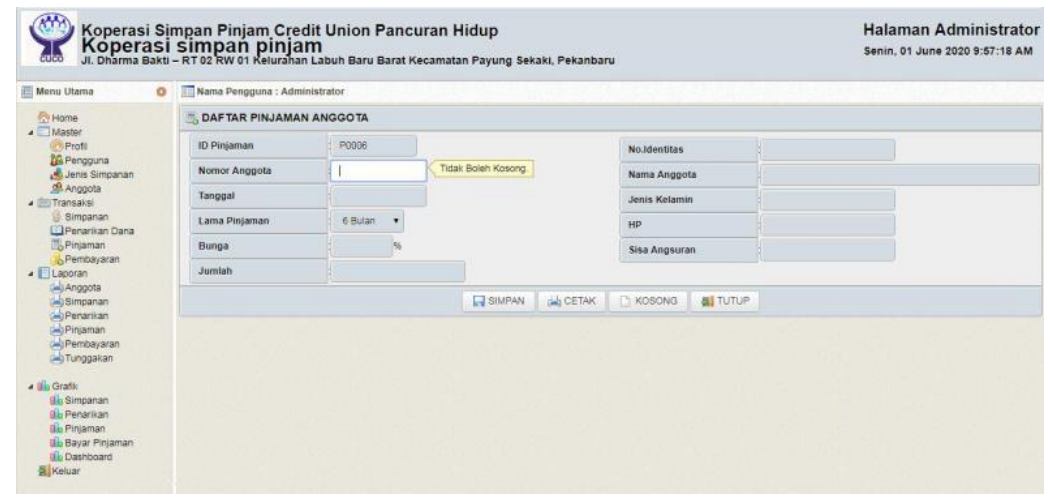

Fig. 9. Admin page Adds Member Loan Data

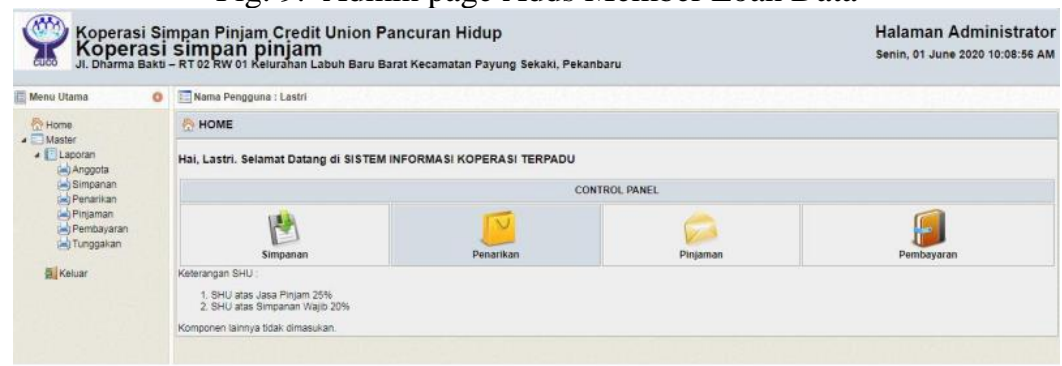

Fig. 10. Main page of the Chairman

\section{Conclusion}

Based on the problems that have been discussed and resolved through this report, the following conclusions can be drawn:

1. A web-based savings and loan information system helps make it easier for employees to manage member data and transactions savings and loans at the Pancuran Hidup Credit Union.

2. Savings and loan information system at Pancuran Hidup Credit Union

\section{References}

Aris, A., Fadillah, M. A., Muttaqin, F. Z., \& Marbun, A. M. V. B. (2016). Aplikasi Sistem Informasi Simpan Pinjam Pada Koperasi Usaha Bersama Syari'Ah At-Tahwil Kota Tangerang. SEMNASTEKNOMEDIA ONLINE, 4(1), 1-4.

Balaji, S., \& Murugaiyan, M. S. (2012). Waterfall vs. V-Model vs. Agile: A comparative study on SDLC. International Journal of Information Technology and Business Management, 2(1), 26-30.

Dao, V., Langella, I., \& Carbo, J. (2011). From green to sustainability: Information Technology and an integrated sustainability framework. The Journal of Strategic Information Systems, 20(1), 63-79.

Kannan, V., Jhajharia, S., \& Verma, S. (2014). Agile vs waterfall: A Comparative Analysis. International Journal of Science, Engineering and Technology Research (IJSETR), 3(10), 2680-2686.

Majee, W., \& Hoyt, A. (2011). Cooperatives and community development: A perspective on the use of cooperatives in development. Journal of community practice, 19(1), 48-61.

Rahmawati, E., Retnasari, T., \& Arifianto, D. (2016). SISTEM INFORMASI SIMPAN PINJAM KOPERASI BERBASIS WEB (Studi Kasus: Koperasi Sejahtera PT. Induro Internasional Tangerang). Jurnal Teknik Komputer, 2(2), 83-88.

Stoica, M., Mircea, M., \& Ghilic-Micu, B. (2013). Software Development: Agile vs. Traditional. Informatica Economica, 17(4). 
Taiwo, J. N. (2016). Effect of ICT on accounting information system and organisational performance: The application of information and communication technology on accounting information system. European Journal of Business and Social Sciences, 5(2), $1-15$.

Wati, H. K., \& Siahaan, K. (2017). Analisis Dan Perancangan Sistem Informasi Koperasi Simpan Pinjam Berbasis Web Pada Mts Negeri Talang Bakung Kota Jambi. Jurnal Manajemen Sistem Informasi, 2(3), 641-660. 